\title{
Using the image drawing method to examine advanced lectures of a teacher librarian program
}

\author{
Daisuke OKADA \\ Yasuda Women's University \\ 6-13-1 Yasuhigashi, Asaminami-ku, Hiroshima 731-0153 \\ Japan, \\ yansenmu@gmail.com
}

Keywords: perception of school libraries, image drawing method (IDM), teacher training, librarian training

\section{Aim}

Previously, I examined changes in the pictures that university students drew of their school library over time while taking a course of school libraries. My lecture explained the importance of school libraries and in particular school librarians to future teachers (excluding school librarians). It was expected that if the lecture objectives had been achieved, the number of students who drew a librarian would increase compared with drawings done by these same students prior to taking part in the course. While my original students showed an increased tendency to draw a librarian, besides only 2 of 22 other teacher librarian courses revealed an increased tendency, the ratio of my students who depicted librarians was at the same level as that of the students in the teacher librarian courses, revealing that my lectures successfully communicated the importance of school librarians.

So, the purpose of this study, to increase the reliability of the image drawing method, and apply to advanced lectures of teacher librarian program.

When applying the method to advanced lectures, the student who just drew a librarian behind a circulation counter is unsatisfying. For the objectives of the courses, there is need to select the new themes in the pictures. And it is unclear the relationship between "understanding the importance of the librarian" and "drew a librarian."

\section{Method}

(1) I determine new themes "Librarian and student(s)," "Communication (e.g. talking or two students read one book) and "Reading."

(2) New three questions are added to the questionnaire; a) wish to work in the school library b) good at drawing c) "Question for behavioral intention" e.g. When you will be a teacher, you 
know a colleague takes counsel with a school librarian. What will you do? I checked the relationship between those questions and the (previous and new) themes.

\section{Results}

(1) In the lecture "Character Development Through Reading," the number of students who depicted the "Communication" increased.

(2) There was a statistical relationship between the "Question for behavioral intention" and "drew a librarian."

\section{Conclusion}

Study findings suggest that IDM can be used as a barometer of advanced lectures of a teacher librarian program.

\section{References}

Okada, D. (2014). Using the image drawing method to examine students' perceptions of school libraries. In Proceedings of the International Association for School Librarians Annual Conference, 205-212, August, 2014. Cosmos Hotel, Moscow.

Okada, D. (2015). How the image drawing method can act as an alternative barometer of librarian instruction. In Proceedings of the International Association for School Librarians Annual Conference, 338-345, November, 2015. MECC, Maastricht.

\section{Biographical note}

Daisuke OKADA has worked as Assistant Professor at Yasuda Women's University in Hiroshima, JAPAN since October 2015; From 2007-2010, he served as a teacher librarian at private junior high school.

He lectures on LIS program. His research interests include the educational effect of the (school or university) library, lesson planning in the library, faculty development from the library, and training in inquiry-based learning for schoolteachers.

$\mathrm{He}$ is the author of Ask essential questions : handbook for inquiry-based learning beginners (in Japanese). 